\title{
Restless legs syndrome
}

This article was published in the following Dove Press journal:

Journal of Parkinsonism \& Restless Legs Syndrome

16 October 2012

Number of times this article has been viewed

\section{Sujith Ovallath \\ P Deepa}

James Parkinson's Movement Disorder Research Centre, Kannur Medical

College, Kerala, India
Correspondence: Sujith Ovallath Department of Neurology, James Parkinson's Movement Disorders Research Centre, Kannur Medical College, Anjarakandy, Kannur,

Kerala, India

Tel +914972856410

Fax +9l 4972852500

Emailsujithok@gmail.com
Background: Restless legs syndrome (RLS) is a common sleep-related disorder characterized by abnormal sensation and an urge to move the lower limbs. Symptoms occur at rest in the evening or at night, and they are alleviated by moving the affected extremity or by walking. Although the exact etiopathogenesis of RLS remains elusive, the rapid improvement of symptoms with dopaminergic agents suggests that dopaminergic system dysfunction may be a basic mechanism. Dopaminergic agents are the best-studied agents, and are considered firstline treatment of RLS.

Objective: To review the diagnostic criteria, clinical features, etiopathogenesis, and the treatment options of RLS.

Methods: The suggestions are based on evidence from studies published in peer-reviewed journals, or upon a comprehensive review of the medical literature.

Results/conclusion: Extensive data are available for proving the link between the dopaminergic system and RLS. A possible genetic link also has been studied extensively. Dopamine agonists, especially pramipexole and ropinirole, are particularly useful in the treatment of RLS. Pharmacological treatment should however be limited to those patients who suffer from clinically relevant RLS with impaired sleep quality or quality of life.

Keywords: dopamine, levodopa, pramipexole

\section{Introduction}

Restless legs syndrome (RLS) is a common neurologic and sleep-related disorder that probably has multiple causes. It is characterized by uncomfortable sensations deep inside the limbs during periods of rest or inactivity, encompassing an irresistible urge to move them, occurring especially during evening hours. The symptoms are typically relieved by movements. ${ }^{1-3}$ The American Sleep Disorder Association has listed RLS among the causes of intrinsic insomnia. ${ }^{4}$ Moreover, the majority of RLS patients suffer from periodic leg movements in sleep (PLMS)..$^{5-9}$

\section{History}

The English physician and anatomist Sir Thomas Willis probably made the first descriptions regarding RLS in the seventeenth century. ${ }^{10,11}$ Symptoms comparable to RLS were described by Boissier de Sauvages in 1763, Magnus Huss in 1849, and Gilles de la Tourette in 1898. ${ }^{12,13}$ In 1945, the Swedish neurologist Karl Axel Ekbom coined the expression "restless legs syndrome" and conducted the first clinical and epidemiological studies on the topic. ${ }^{14,15}$ In 1995, the International Restless Legs 
Syndrome Study Group developed standardized diagnostic criteria for the disease, which was updated in $2003 .^{3}$

\section{Epidemiology}

The prevalence of RLS among Caucasians ranges from 5\% to $15 \% .^{2,16-18}$ The prevalence tends to escalate with age, with a higher occurrence among women. The disease manifests itself usually in the fourth and fifth decades. ${ }^{2,19-21}$

Epidemiological studies are available mostly in Caucasians. Reports from Asian countries document a lower prevalence. ${ }^{22,23}$ The discrepancy could be explained by the interplay of genetic and environmental factors and cultural differences.

\section{Possible etiological factors}

RLS is a disease with multisystem correlates, and so its exact etiology has not been delineated Table 1. It has been documented that dopamine antagonists that cross the blood-brain barrier (like metoclopramide) aggravate features of RLS. However, the peripheral antidopaminergic domperidone, which does not cross the blood-brain barrier, does not result in RLS either. ${ }^{24,25}$ On high-resolution functional magnetic resonance imaging, increased activity was uncovered in the cerebellum, thalamus, red nucleus, and inferior olive. No cortical activation was noted, and no structural abnormality was discovered. ${ }^{26-28}$ Bara-Jimenez and colleagues described an abnormally increased spinal flexor reflex excitability during sleep in RLS patients, ${ }^{29}$ hinting at the probability of a reversal of circadian-associated spinal cord inhibition. ${ }^{30}$ Therefore, the accessible evidence suggests that RLS is a disorder of the central nervous system, more or less subcortical in nature. This also suggests the hypothesis of a neuronal network connecting the aforementioned areas, resulting in the sensorimotor symptoms of RLS. ${ }^{30,31}$

An abrupt, universal, and almost overall response to RLS symptoms follows the administration of dopaminergic medications. Double-blinded and placebo-controlled studies have validated the advantages of levodopa ${ }^{32-34}$ and dopamine agonists like pergolide, ${ }^{35,36}$ pramipexole, ${ }^{37}$ and ropinirole ${ }^{38}$ over other medications. Additionally, they are beneficial at substantially lower doses when compared to their respective doses for Parkinson's disease. All other medications used to treat RLS need high doses for symptomatic relief. ${ }^{39,40}$ The opioid antagonist naloxone does not increase RLS symptoms, whereas dopaminergic antagonists like pimozide and metoclopramide have been well documented to exacerbate it. ${ }^{41}$

Even though evaluation during a symptomatic period has not been attempted, ${ }^{42}$ brain-imaging studies using positron emission tomography and single-photon emission computed tomography have disclosed that presynaptic $\mathrm{D}_{2}$ receptor binding was remarkably reduced, whereas postsynaptic binding was more or less normal. A possibility of decrease in either the number of $\mathrm{D}_{2}$ receptors or their affinity towards dopamine was suggested. The rate of dopamine production seems to be normal or slightly decreased. ${ }^{43-46}$

Research by Garcia-Borreguero and colleagues revealed that levodopa-induced inhibition of prolactin secretion links significantly with polysomnographic findings in RLS/PLMS. ${ }^{47}$ Dopaminergic pathology was thus proposed. Dysfunction in a number of pathways is suggested, the most appropriate candidate being the A11 or dorsoposterior hypothalamus system. However, the contributions of nigrostriatal (A9) and tuberoinfundibular systems cannot be excluded. ${ }^{31,48}$

The recognized secondary causes of RLS, including end-stage renal disease, ${ }^{49-51}$ pregnancy, ${ }^{52,53}$ iron-deficiency anemia, ${ }^{54}$ gastric surgery, ${ }^{55,56}$ and frequent blood donations, ${ }^{57}$ are all linked with a decrement in body iron stores. Remission has been reported with iron therapy. ${ }^{58,59}$ Earley and colleagues demonstrated that cerebrospinal fluid (CSF) concentrations of ferritin were significantly lower in RLS patients while maintaining a more or less normal serum ferritin level. ${ }^{60}$ A reduced central nervous system iron status was proposed, even with a high normal serum ferritin level, the slope of their relationship being abnormally low in RLS. ${ }^{61}$ Studies using magnetic resonance imaging have revealed diminished iron content in substantia nigra. ${ }^{62}$ Autopsy reports suggest reduced $\mathrm{H}$-ferritin and iron content, and abnormal distribution of L-ferritin in the nigral cells. ${ }^{63}$

Iron is a cofactor for tyrosine hydroxylase, the ratelimiting enzyme in dopamine synthesis. Hence iron deficiency may result in dopaminergic dysfunction. Studies show that rats fed an iron-deficient diet had reduced $D_{1}$ and $\mathrm{D}_{2}$ receptors in caudate putamen, with decreased dopamine transporter function. ${ }^{64}$ Reports regarding brain iron content and dopaminergic dysfunction often converge at identical points. Moreover, the circadian patterns of serum iron and dopamine levels coincide smoothly with those of RLS symptoms. A possible, yet to be explored, interplay of iron and dopamine pathophysiology is thus hinted at. ${ }^{30}$

\section{Genetics of RLS}

Roughly $65 \%$ of RLS patients, especially those with an early onset of symptoms, have at least one first-degree relative with the disease. ${ }^{7,65-67}$ The concordance rate between monozygotic twins also has been reported to be high. ${ }^{68}$ Most pedigrees suggest an autosomal dominant inheritance, even though 


\section{Table I}

Etiological classification

Primary/idiopathic RLS

Secondary RLS

- Iron deficiency

- End-stage renal disease

- Pregnancy

- Frequent blood donations

- Rheumatic disease

- Drugs

- Antihistamines

- Dopamine antagonists

- Mirtazapine

- Tricyclic antidepressants

- Selective serotonin reuptake inhibitors

recessive models have been proposed as well. Differences in penetrance and anticipation may explain the heterogeneity in expression. ${ }^{66,69}$ Several chromosomal loci have been reported (on 12q, 14q, 9p, 2q, 20p, and 16p). Sequence variants have also been proposed, in or around genes on $6 \mathrm{p}, 2 \mathrm{p}$, or $15 \mathrm{q} \cdot{ }^{70-77}$ The most significant gene identified to this point would be MEIS $1,{ }^{78}$ others being $N O S 1^{74}$ and BTBD9. ${ }^{79}$

\section{Cardinal features Uncomfortable and unpleasant sensations in the limbs}

RLS is characterized by uncomfortable or distressing sensations deep inside the limbs, commonly between the ankle and knee. Arms are involved now and then, and so are thighs and feet. The sensory experience may be described as "creepycrawly," burning, tingling, aching, or cramping. The perception is generally bilateral and symmetrical, but unilateral presentations are not infrequent. Predominant symptoms in the upper limbs without involving legs and extension to other body parts are unusual and atypical of RLS. ${ }^{1,2}$

\section{An urge to move}

The sensations are accompanied by an irresistible urge to move the affected limb. This is different from the generalized inner restlessness or fidgetiness of neuroleptic-induced akathisia $^{1,2}$ and may persist for hours on end until a movement is initiated.

\section{Association with rest and circadian rhythm}

The symptoms appear classically when the patient puts his limbs at rest or during evening hours. He may feel them during a train or air journey, at the theater, or during a conference; alternatively, he suffers on getting to bed. Many patients experience a worsening of symptoms during the night, regardless of them resting. Thus, the diurnal variation seems independent from inactivity. ${ }^{1,2,80}$

\section{Relief on movement}

Dramatic and immediate symptomatic relief, either complete or partial, is gained by movement of the affected limb. It prevails as long as the activity is continued. Activities like walking, stretching, or massaging may be helpful. The patient may wake up from sleep and be forced to walk around for relief, the behavior being termed 'night-walker syndrome.' $1,2,9$

\section{Periodic limb movements}

RLS is commonly accompanied by involuntary, rhythmic muscular jerks in lower limbs, called periodic limb movements. The classic picture is a regular extension or fanning of toes and dorsiflexion of the ankle, with infrequent flexion at knee and hip. When occurring during sleep, it is termed PLMS. This may occur every 20-40 seconds, occurring throughout the sleep span. Each movement results in a brief microarousal (of which the patient may not be aware), resulting in sleep fragmentation. Thus most of the time, the only complaint regarding PLMS is insomnia or excessive daytime sleepiness. History noted from a bed partner is often valuable. Diagnosis is essentially by an overnight polysomnogram. In fact, more than $80 \%$ of RLS patients suffer from PLMS. PLM occurring during a wakeful period is called PLMW, usually provoked by a suggested immobilization test. ${ }^{5,81-84}$

\section{Disease course}

RLS can present at any age..$^{30,85-87}$ Generally regarded as a chronic disease with progressive intensification of symptoms over years, two major phenotypes have been described. There are people in whom symptoms manifest before 45 years of age. The probability of them having a positive family history is high, and the disease assumes rather a slow course in them (early onset phenotypes). In the other group, in which the disease appears late (the late-onset group), the symptoms are rapidly progressive. The disparities in clinical course suggest a marked difference in pathology between the two. ${ }^{2,23,30,88,89}$ The early onset group comprises mainly those with the familial form of the disease, whereas the late-onset cluster consists more of sporadic RLS. The latter has been more often associated with secondary causes of RLS. ${ }^{87}$ 


\section{Diagnosis}

The diagnosis of RLS is essentially based on history. In 1995, the International Restless Legs Syndrome Study Group developed standardized diagnostic criteria for the disease, which were updated in 2003..$^{2,3,90}$ See Table 2.

\section{Diagnosis of PLM}

PLMS is diagnosed based on an overnight polysomnogram. To diagnose PLMS, a PLM index (number of periodic limb movements per hour of sleep) $\geq 5$ is required. ${ }^{83}$ PLMS itself is not diagnostic of RLS, since it may occur as a result of sleepdisordered breathing or adverse drug effects. Nonetheless, a high PLMS index offers a sensitive and specific diagnostic norm. ${ }^{4,7,8}$ Montplaisir and colleagues suggested that the incidence of PLMW in RLS strongly supports the diagnosis. ${ }^{8}$ It even seems to be more specific than PLMS, but adequate evidence is lacking. ${ }^{91,92}$

Studies affirm that $1.9 \%$ of school-going children and $2 \%$ of adolescents suffer from RLS/PLMS. ${ }^{93}$ Identification of symptoms and an effective communication regarding the same can be quite challenging for a child. Up to the age of 12 years, a definite diagnosis of RLS is made only if the child describes in his or her own words a set of sensations coherent with leg discomfort, besides fulfilling the four essential criteria. The adult criteria are considered appropriate for an adolescent $(>12$ years old $){ }^{94}$

\section{Differential diagnosis}

Many diseases mimic RLS but do not fulfill the essential diagnostic criteria. A few examples are given below.

Table 2 Diagnostic criteria for restless legs syndrome (RLS)

\section{Essential criteria}

I. An urge to move the legs, usually accompanied or caused by uncomfortable and unpleasant sensations in the legs.

2. The urge to move or unpleasant sensations begin or worsen during periods of rest or inactivity, such as lying or sitting.

3. The urge to move or unpleasant sensations are partially or totally relieved by movement, such as walking or stretching.

4. The urge to move or unpleasant sensations are worse in the evening or night than during the day or only occur in the evening or night.

Supportive clinical features

I. Positive family history.

2. Positive response to dopaminergic therapy.

3. Presence of periodic limb movements (during wakefulness or sleep). Associated features of RLS

I. Variable clinical course, but typically chronic and often progressive.

2. Physical examination normal in idiopathic/familial forms.

3. Sleep disturbance is a common complaint in more affected patients.

Notes: All four essential criteria have to be fulfilled for a definite diagnosis of RLS. The supportive criteria are helpful but not necessary. Needed investigations include serum ferritin and other investigations to rule out secondary causes.
- Akathisia: a generalized motor restlessness with movement stereotypy, usually neuroleptic-induced

- Nocturnal leg cramps

- Positional discomfort: relieved by changing the limb position

- Painful legs and moving toes: involuntary, spontaneous flexion and extension of toes, secondary to cord or root lesions

- Peripheral neuropathy

- Lumbosacral radiculopathy

- Attention deficit/hyperactivity disorder (ADHD)

\section{Consequences of RLS/PLMS}

Increased daytime sleepiness results in an overall decline in the quality of life in these patients. Depression is found frequently, possibly due to underlying brain pathology, insomnia, or psychological stress due to the chronic illness. ${ }^{95,96}$ Treatment should be cautious, since antidepressants can aggravate the symptoms. Social and occupational disruption, ${ }^{18,19}$ headaches, ${ }^{18,19}$ sleep-disordered breathing, ${ }^{100}$ difficulty in concentration, and short-term-memory defects have been reported.${ }^{97} \mathrm{RLS}$ and PLMS are associated with increased risk of hypertension, ${ }^{98,99}$ cardiovascular disease, ${ }^{100}$ and stroke. ${ }^{101}$ Sympathetic overactivity, ${ }^{102,103}$ increment in atherosclerotic plaque formation ${ }^{104}$ and rupture, and sleep disturbances are the proposed causal factors. ADHD has been reported in children with RLS. ${ }^{97}$

\section{Treatment}

Primary RLS

Primary RLS can be treated by nonpharmacological and pharmacological measures.

\section{Nonpharmacological treatment}

Improvement of sleep hygiene has been found effective in combating sleep fragmentation. ${ }^{105} \mathrm{~A}$ regular sleep pattern; avoidance of alcohol, coffee, and tobacco; moderate exercises; thermal baths; and massages may help in assuring a sound sleep. ${ }^{106}$ Hornyak and colleagues studied the impact of cognitive behavioral therapy in RLS and reported symptomatic improvement. ${ }^{107}$

\section{Pharmacological treatment Levodopa}

The response to levodopa is immediate and occurs at low doses relative to that used in Parkinson's disease. ${ }^{32-34}$ In spite of this, the therapeutic benefit is limited by afternoon augmentation and morning-rebound phenomena. Augmentation 
is characterized by an earlier onset of RLS symptoms (in the afternoon or early evening), with greater intensity or with involvement of other body parts. Curiously, intense dopaminergic therapy as well as iron deficiency and sleep deprivation result in augmentation. ${ }^{108-111}$ The reappearance of symptoms can occur in the morning hours, possibly owing to the short plasma half-life of levodopa, and is termed morning rebound. ${ }^{106}$

\section{Dopaminergic agonists}

Presently, dopaminergic agonists are considered the first-line pharmacological therapy for RLS/PLMS. A longer half-life and fewer incidences of side effects like augmentation ${ }^{123}$ are the major reasons for their current status, backed by doubleblind placebo-controlled trials. The non-ergot derived drugs pramipexole and ropinirole are both effective, ${ }^{112-117}$ and can be used long-term. ${ }^{118,119}$ Between these, pramipexole seems to be the better choice in view of earlier efficacy, superior response, and fewer adverse effects. ${ }^{120,121}$ Trenkwalder et al demonstrated the benefits of transdermal rotigotine in RLS. Interestingly, the transdermal preparation did not accommodate signs of augmentation during the study. ${ }^{122}$ Concerns with regard to pulmonary fibrosis and cardiac dysfunction have made treatment with pergolide obsolete. ${ }^{124-127}$

\section{Antiepileptics}

Gabapentin is the favored treatment for a patient who cannot tolerate dopaminergics. It is as effective as ropinirole in relieving RLS/PLMS. ${ }^{128,129}$ The mechanism of action is unclear. The only known side effect is minimal daytime sleepiness. The other evaluated anticonvulsants, like carbamazepine and valproate, are better avoided because of worse side effects and drug interactions. ${ }^{130}$

\section{Opioids}

Short-term as well as long-term therapeutic benefits have been described in RLS when opioids were administered, as per clinical trials. ${ }^{123}$ They could be considered as second-line therapy in refractory RLS. ${ }^{131,132}$ The drugs proved beneficial were oxycodone, ${ }^{133}$ methadone, ${ }^{134}$ and tramadol. ${ }^{135}$ Side effects like nausea, vomiting, urinary retention, constipation, and dizziness are common. Apprehension regarding abuse potential and respiratory depression is also a factor. Vetrugno et al reported augmentation on long-term tramadol therapy. ${ }^{136}$

\section{Benzodiazepines}

Benzodiazepines work mainly on the quality of sleep, and not on the pathology of RLS, clonazepam being the most recognized one. ${ }^{137}$ In the current scenario, they are not regarded as an ideal therapy for RLS. Psychological dependence and physiological tolerance are major concerns about their prescription. However, they may be useful in RLSassociated insomnia refractory to treatment. ${ }^{138}$

\section{Secondary RLS}

The management of secondary RLS is converged at identifying and treating the specific causes. Provocative medications like dopaminergic antagonists, antipsychotics, and antidepressants should be discontinued, tapered, or administered early during daytime. In the depressed, bupropion may be used, considering its beneficial effect on PLM. ${ }^{4}$

Therapeutic benefits have been observed in studies concerning parenteral iron treatment (intravenous iron dextran) in idiopathic as well as secondary RLS. ${ }^{58,59}$ Since higher serum levels of ferritin are sometimes associated with low normal CSF ferritin, it is advisable to consider parenteral iron therapy if first-line pharmaceuticals fail to bring about a response. This could be done irrespective of serum ferritin levels. If serum ferritin drops beneath $50 \mu \mathrm{g} / \mathrm{mL}$, oral iron may be started in the form of $325 \mathrm{mg}$ iron sulfate three times a day, along with vitamin C. Gastrointestinal irritation is a limiting factor for oral therapy; allergic reactions often restrict intravenous iron treatment. ${ }^{4}$

RLS associated with ESRD is often refractory and does not improve with hemodialysis. ${ }^{139,140} \mathrm{~A}$ fruitful renal transplantation may result in significant symptomatic improvement. ${ }^{141,142}$

Pregnancy-related RLS has been reported to resolve completely after delivery. ${ }^{143}$ Vitamin $\mathrm{B}_{12}$ and folic acid deficiency may lead to RLS, and so do neuropathies. The primary condition should be treated then. ${ }^{146,154,156,157}$ Papers based on clinical trials suggest that gabapentin ${ }^{131}$ and pregabalin ${ }^{147}$ are especially useful in neuropathy-associated RLS. ${ }^{97}$

\section{Treatment in children and during pregnancy}

There is no single FDA-approved medication for pediatric RLS. Studies have stated the efficacy of levodopa and dopaminergic agonists in childhood RLS and associated ADHD. ${ }^{148-150}$ However, clonazepam may be avoided in children with ADHD since it may aggravate hyperactivity. ${ }^{151}$ Iron therapy may be beneficial when serum ferritin levels are low. ${ }^{152,153}$ Drugs are generally not recommended in pregnancy-related RLS in view of inconsistent reports on their safety and the benign nature of the condition. ${ }^{4}$ 


\section{RLS studies from the Indian subcontinent}

There are a few reports of prevalence of RLS from India. The first Indian population study on RLS revealed prevalence of the disorder in South India at 2.1\%. ${ }^{159}$ Another trial reported that RLS had a predominance of females, and that they were younger than the male counterparts. ${ }^{160}$ A Hindi-language version of the RLS scale has been developed for easy administration of the questionnaire in the local language. ${ }^{161}$

\section{Conclusion}

RLS is a very common sleep-related movement disorder, but it is mild in the majority of cases. The etiology of RLS is only partly understood. Some medical conditions, including renal failure, iron deficiency, and pregnancy, are associated with high rates of RLS. Most patients with idiopathic RLS respond well to dopaminergic agents. Second-line treatment options include gabapentin or similar antiepileptic drugs and opioids. Pharmacological treatment should be limited to those patients who suffer from clinically relevant symptoms.

\section{Disclosure}

The authors report no conflicts of interest in this work.

\section{References}

1. Trenkwalder C, Paulus W, Walters AS. The restless legs syndrome. Lancet Neurol. 2005;4:465-475.

2. Allen RP, Picchietti D, Hening WA, et al. Restless legs syndrome: diagnostic criteria, special considerations and epidemiology. A report from the restless legs syndrome diagnosis and epidemiology workshop at the National Institute of Health. Sleep Med. 2003;4:101-119.

3. American Sleep Disorders Association, Diagnostic Classification Steering Committee. International Classification of Sleep Disorders. Diagnostic and Coding Manual. 2nd ed. Westchester: American Academy of Sleep Medicine; 2005.

4. Zucconi M, Manconi M. Sleep disturbances in restless leg syndrome (RLS) and periodic limb movements(PLM). In: Pandi-Perumal SR, Monti JM, editors. Clinical Pharmacology of Sleep. Basel: Birkhäuser Verlag; 2006:61-79.

5. Lugaresi E, Tassinari CA, Coccagna G, Ambrosetto C. Particularités cliniques et polygraphiques du syndrome d'impatience des membres inférieurs. (Clinical and polygraphic syndrome in lower limbs). Rev Neurol (Paris). 1965;113:545-555. (French).

6. Coleman RM. Periodic movements in sleep (nocturnal myoclonus). In: Guilleminault C, editor. Sleeping and Waking Disorders: Indications and Techniques. Menlo Park: Addison Wesley; 1982.

7. Montplaisir J, Boucher S, Poirier G, Lavigne G, Lapierre O, Lesperance P. Clinical, polysomnographic, and genetic characteristics of restless legs syndrome: a study of 133 patients diagnosed with new standard criteria. Mov Disord. 1997;12:61-65.

8. Montplaisir J, Boucher S, Nicolas A, et al. Immobilization tests and periodic leg movements in sleep for the diagnosis of restless leg syndrome. Mov Disord. 1998;13:324-329.

9. Ekbom K, Ulfberg J. Restless legs syndrome. J Intern Med. 2009;266:419-431.
10. Blom S, Ekbom KA. Comparison between akathisia developing on treatment with phenothiazine derivatives and the restless legs syndrome. Acta Med Scand. 1961;170:689-694.

11. Willis T. The London Practice of Physick. London: Thomas Basset and William Crook; 1685.

12. Ekbom K, Ekbom KA. An early Swedish description of restless legs (Huss 1849). Lakartidningen. 1974;71:2905-2906. Swedish.

13. Konofal E, Karroum E, Montplaisir J, Derenne JP, Arnulf I. Two early descriptions of restless syndrome and periodic leg movements by Boissier de Sauvages (1763) and Gilles de la Tourette (1898). Sleep Med. 2009;10:586-591.

14. Ekbom KA. Restless legs. Acta Med Scand. 1945;158:1-123.

15. Ekbom KA. Restless legs syndrome. Neurology. 1960;10:868-873.

16. Hening W, Walters AS, Allen RP, et al. Impact, diagnosis and treatment of restless legs syndrome (RLS) in a primary care population: the REST (RLS epidemiology, symptoms, and treatment) primary care study. Sleep Med. 2004;5:237-246.

17. Rothdach AJ, Trenkwalder C, Haberstock J, Keil U, Berger K. Prevalence and risk factors of RLS in an elderly population: the MEMO study. Memory and Morbidity in Augsburg Elderly. Neurology. 2000;54:1064-1068.

18. Berger K, Luedemann J, Trenkwalder C, John U, Kessler C. Sex and risk of restless legs syndrome in the general population. Arch Intern Med. 2004;164:196-202.

19. Ulfberg J, Nyström B, Carter N, Edling C. Prevalence of restless legs syndrome among men aged 18 to 64 years: an association with somatic disease and neuropsychiatric symptoms. Mov Disord. 2001;16:1159-1163.

20. Ulfberg J, Nyström B, Carter N, Edling C. Restless legs syndrome among working-aged women. Eur Neurol. 2001;46:17-19.

21. Bjorvatn B, Leissner L, Ulfberg J, et al. Prevalence, severity and risk factors of restless legs syndrome in the general adult population in two Scandinavian countries. Sleep Med. 2005;6:307-312.

22. Cho SJ, Hong JP, Hahm BJ, et al. Restless legs syndrome in a community sample of Korean adults: prevalence, impact on quality of life, and association with DSM-IV psychiatric disorders. Sleep. 2009;32:1069-1076.

23. Sevim S, Dogu O, Camdeviren H, et al. Unexpected low prevalence and unusual characteristics of RLS in Mersin, Turkey. Neurology. 2003;61:1562-1569.

24. Winkelmann J, Schadrack J, Wetter TC, Zieglgansberger W, Trenkwalder C. Opioid and dopamine antagonist drug challenges in untreated restless legs syndrome patients. Sleep Med. 2001;2: $57-61$.

25. Wetter TC, Stiasny K, Winkelmann J, et al. A randomized controlled study of pergolide in patients with restless legs syndrome. Neurology. 1999;52:944-950.

26. Bucher SF, Seelos KC, Oertel WH, Reiser M, Trenkwalder C. Cerebral generators involved in the pathogenesis of the restless legs syndrome. Ann Neurol. 1997;41:639-645.

27. Lugaresi E, Cirignotta F, Coccagna G, Montagna P. Nocturnal myoclonus and restless legs syndrome. In: Fahn S, Marsden CD, Van Woert MH, editors. Myoclonus. New York: Raven Press; 1986.

28. Trenkwalder C, Bucher SF, Oertel WH, Proeckl D, Plendl H, Paulus W. Bereitschafts potential in idiopathic and symptomatic restless legs syndrome. Electroencephalogr Clin Neurophysiol. 1993;89:95-103.

29. Bara-Jimenez W, Aksu M, Graham B, Sato S, Hallett M. Periodic limb movements in sleep: state-dependent excitability of the spinal flexor reflex. Neurology. 2000;54:1609-1615.

30. Allen RP, Earley CJ. Restless legs syndrome: a review of clinical and pathophysiologic features. J Clin Neurophysiol. 2001;18:128-147.

31. Trenkwalder C, Paulus W. Why do restless legs occur at rest? Pathophysiology of neuronal structures in RLS. Neurophysiology of RLS (part 2). Clin Neurophysiol. 2004;115:1975-1988.

32. Brodeur C, Montplaisir J, Godbout R, Marinier R. Treatment of restless legs syndrome and periodic movements during sleep with $\mathrm{L}$ dopa: a double-blind, controlled study. Neurology. 1988;38:1845-1848. 
33. Von Scheele C. Levodopa in restless legs. Lancet.1986;2:426-427.

34. Trenkwalder C, Stiasny K, Pollmacher T, et al. L-Dopa therapy of uremic and idiopathic restless legs syndrome: a double-blind, crossover trial. Sleep. 1995; 18:681-688.

35. Earley CJ, Yaffee JB, Allen RP. Randomized, double-blind, placebo controlled trial of pergolide in restless legs syndrome. Neurology. 1998;51:1599-1602.

36. Wetter TC, Stiasny K, Winkelmann J. A randomized controlled study of pergolide in patients with restless legs syndrome. Neurology. 1999;52:944-950.

37. Montplaisir J, Nicolas A, Denesle R, Gomez-Mancilla B. Restless legs syndrome improved by pramipexole: a double-blind randomized trial. Neurology. 1999;52:938-943.

38. Freeman A, Rye D, Bliwise DL, et al. Ropinirole for restless legs syndrome (RLS): an open-label and double-blind placebo-controlled study. Neurology. 2001;56:A5.

39. Walters AS, Wagner ML, Hening WA, et al. Successful treatment of the idiopathic restless legs syndrome in a randomized double-blind trial of oxycodone versus placebo. Sleep. 1993;16:327-332.

40. Garcia-Borreguero D, Larrosa O, De la Llave Y, et al. Treatment of restless legs syndrome with gabapentin: a double-blind, cross-over study. Neurology. 2002;59:1573-1579.

41. Winkelmann J, Schadrack J, Wetter TC, et al. Opioid and dopamine antagonist drug challenges in untreated restless legs syndrome patients. Sleep Med. 2001;2:57-61.

42. Winkelman JW. Considering the causes of RLS. Eur J Neurol. 2006;13:8-14.

43. Staedt J, Stoppe G, Kogler A, et al. Nocturnal myoclonus syndrome (periodic movements in sleep) related to central dopamine D2-receptor alteration. Eur Arch Psychiatry Clin Neurosci. 1995;245:8-10.

44. Staedt J, Stoppe G, Kogler A, et al. Dopamine D2 receptor alteration in patients with periodic movements in sleep (nocturnal myoclonus). J Neural Transm Gen Sect. 1993;93:71-74.

45. Ruottinen HM, Partinen M, Hublin C, et al. An FDOPA PET study in patients with periodic limb movement disorder and restless legs syndrome. Neurology. 2000;54:502-504.

46. Michaud M, Soucy JP, Chabli A, Lavigne G, Montplaisir J. SPECT imaging of striatal pre- and postsynaptic dopaminergic status in restless legs syndrome with periodic leg movements in sleep. $J$ Neurol. 2002;249:164-170.

47. Garcia-Borreguero D, Larrosa O, Granizo JJ, de la Llave Y, Hening WA. Circadian variation in neuroendocrine response to L-dopa in patients with restless legs syndrome. Sleep. 2004;27:669-673.

48. Ondo WG, He Y, Rajasekaran S, Le WD. Clinical correlates of 6-hydroxydopamine injections into A11 dopaminergic neurons in rats: a possible model for restless legs syndrome. Mov Disord. 2000;15:154-158.

49. Collado-Seidel V, Kohnen R, Samtleben W, et al. Clinical and biochemical findings in uremic patients with and without restless legs syndrome. Am J Kidney Dis. 1998;31:324-328.

50. Hui DS, Wong TY, Ko FW, et al. Prevalence of sleep disturbances in Chinese patients with end-stage renal failure on continuous ambulatotory peritoneal dialysis. Am J Kidney Dis. 2000;36:783-788.

51. Winkelman JW, Chertow GM, Lazarus JM. Restless legs syndrome in end-stage renal disease. Am J Kidney Dis. 1996;28:372-378.

52. Kurella B, Kraemer S, Winkler P. Restless legs syndrome and pregnancy. Results of a questionnaire-study. German Neurological Society; September 26-29, 2002; Göttingen, Germany.

53. Lee KA, Zaffke ME, Baratte-Beebe K. Restless legs syndrome and sleep disturbance during pregnancy: the role of folate and iron. $J$ Womens Health Gend Based Med. 2001;10:335-341.

54. Ekbom KA. Restless legs: a clinical study. Acta Med Scand Suppl. $1945 ; 158: 1-122$

55. Ekbom KA. Restless legs syndrome after partial gastrectomy. Acute Neurol Scand. 1966;42:79-89.

56. Banerji N, Hurwitz L. Restless legs syndrome, with particular reference to its occurrence after gastric surgery. Br Med J. 1970;4:774-775.
57. Silber MH, Richardson JW. Multiple blood donations associated with iron deficiency in patients with restless legs syndrome. Mayo Clin Proc. 2003;78:52-54.

58. Earley CJ, Heckler D, Allen RP. The treatment of restless legs syndrome with intravenous iron dextran. Sleep Med. 2004;5:231-235.

59. Sloand JA, Shelly MA, Feigin A, Bernstein P, Monk RD. A doubleblind, placebo-controlled trial of intravenous iron dextran therapy in patients with ESRD and restless legs syndrome. Am J Kidney Dis. 2004;43:663-670.

60. Earley CJ, Connor JR, Beard JL, Malecki EA, Epstein DK, Allen RP. Abnormalities in CSF concentrations of ferritin and transferrin in restless legs syndrome. Neurology. 2000;54:1698-1700.

61. Allen R. Dopamine and iron in the pathophysiology of restless legs syndrome (RLS). Sleep Med. 2004;5:385-391.

62. Allen RP, Barker PB, Wehrl F, et al. MRI measurement of brain iron in patients with restless legs syndrome. Neurology. 2001;56:263-265.

63. Boyer PJ, Ondo WG, Allen RP, et al. Neuropathologic evaluation of the central nervous system in restless legs syndrome: case report and review of literature. Soc Neurosci. 2000;2:2060.

64. Erikson KM, Jones BC, Hess EJ, Zhang Q, Beard JL. Iron deficiency decreases dopamine D1 and D2 receptors in rat brain. Pharmacol Biochem Behav. 2001;69:409-418.

65. Allen RP, LaBuda MC, Becker P, Earley CJ. Family history study of the restless legs syndrome. Sleep Med. 2002;3:S3-S7.

66. Lazzarini A, Walters AS, Hickey K, et al. Studies of penetrance and anticipation in five autosomal-dominant restless legs syndrome pedigrees. Mov Disord. 1999;14:111-116.

67. Winkelmann J, Muller-Myhsok B, Wittchen HU, et al. Complex segregation analysis of restless legs syndrome provides evidence for an autosomal dominant mode of inheritance in early age at onset families. Ann Neurol. 2002;52:297-302.

68. Ondo WG, Vuong KD, Wang Q. Restless legs syndrome in monozygotic twins: clinical correlates. Neurology. 2000;55:1404-1406.

69. Trenkwalder C, Seidel VC, Gasser T, Oertel WH. Clinical symptoms and possible anticipation in a large kindred of familial restless legs syndrome. Mov Disord. 1996;11:389-394.

70. Desai AV, Cherkas LF, Spector TD, Williams AJ. Genetic influences in self-reported symptoms of obstructive sleep apnoea and legs: a twin study. Twin Res. 2004;7:589-595.

71. Levchenko A, Montplaisir JY, Asselin G, et al. Autosomal dominant locus for restless legs syndrome in French-Canadians on chromosome 16p12.1. Mov Disord. 2009;24:40-50.

72. Lohmann-Hedrich K, Neumann A, Kleensang A, et al. Evidence for linkage of restless legs syndrome to chromosome 9p: are there two distinct loci? Neurology. 2008;70:686-694.

73. Pichler I, Hicks AA, Pramstaller PP. Restless legs syndrome: an update on genetics and future perspectives. Clin Genet. 2008;73:297-305.

74. Winkelmann J, Lichtner P, Schormair B, et al. Variants in the neuronal nitric oxide synthase (nNOS, NOS1) gene are associated with restless legs syndrome. Mov Disord. 2008;23:350-358.

75. Winkelmann J, Polo O, Provini F, et al. Genetics of restless legs syndrome (RLS): state-of-the-art and future directions. Mov Disord. 2007;22:S449-S458.

76. Winkelmann J, Schormair B, Lichtner P, et al. Genome-wide association study of restless legs syndrome identifies common variants in three genomic regions. Nat Genet. 2007;39:1000-1006.

77. Young JE, Vilarino-Guell C, Lin SC, Wszolek ZK, Farrer M. Clinical and genetic description of a family with a high prevalence of autosomal dominant restless legs syndrome. Mayo Clin Proc. 2009;84:134-138.

78. Xiong L, Catoire H, Dion P, et al. MEIS1 intronic risk haplotype associated with restless legs syndrome affects its mRNA protein expression levels. Hum Mol Genet. 2009;18:1065-1074.

79. Stefansson H, Rye DB, Hicks A, et al. A genetic risk factor for periodic limb movements in sleep. N Engl J Med. 2007;357:639-647.

80. Trenkwalder C, Hening WA, Walters AS. Circadian rhythm of periodic limb movements and sensory symptoms of restless legs syndrome. Mov Disord. 1999;14:102-110. 
81. Montplaisir J, Boucher S, Poirier G, Lavigne G, Lapierre O, Lesperance P. Clinical, polysomnographic, and genetic characteristics of restless legs syndrome: a study of 133 patients diagnosed with new standard criteria. Mov Disord. 1997;12:61-66.

82. Montplaisir J, Boucher S, Nicolas A, et al. Immobilization tests and periodic leg movements in sleep for the diagnosis of restless leg syndrome. Mov Disord. 1998;13:324-329.

83. Neikrug AB, Ancoli-Israel S. Sleep disorders in the older adult - a mini review. Gerontology. 2010;56:181-189.

84. Scofield H, Roth T, Drake C. Periodic limb movements during sleep: population prevalence, clinical correlates, and racial differences. Sleep. 2008;31:1221-1227.

85. Walters AS, Picchietti D, Hening W, Lazzarini A. Variable expressivity in familial restless legs syndrome. Arch Neurol. 1990;47:1219-1220.

86. Walters AS, Picchietti DL, Ehrenberg BL, Wagner ML. Restless legs syndrome in childhood and adolescence. Pediatr Neurol. 1994;11:241-245.

87. Allen RP, Earley CJ. Defining the phenotype of the restless leg syndrome (RLS) using age-of-symptom-onset. Sleep Med. 2000;1:11-19.

88. Milligan SA, Chesson AL. Restless legs syndrome in the older adult: diagnosis and management. Drugs Aging. 2002;19:741-751.

89. Kushida CA. Clinical presentation, diagnosis, and quality of life issues in restless legs syndrome. Am J Med. 2007;120:4-12.

90. Walters AS. Toward a better definition of the restless legs syndrome. The International Restless Legs Syndrome Study Group. Mov Disord. 1995; 10:634-642.

91. Nicolas A, Michaud M, Lavigne G, Montplaisir J. The influence of sex, age and sleep/wake state on characteristics of periodic leg movements in restless legs syndrome patients. Clin Neurophysiol. 1999;110: $1168-1174$.

92. Michaud M, Lavigne G, Desautels A, Poirier G, Montplaisir J. Effects of immobility on sensory and motor symptoms of restless legs syndrome. Mov Disord. 2002;17:112-115.

93. Picchietti D, Allen RP, Walters AS, Davidson JE, Myers A, Ferini Strambi L. Restless legs syndrome: prevalence and impact in children and adolescents - the Peds REST Study. Pediatrics. 2007; 120:253-266.

94. Allen RP, Picchietti D, Hening WA, et al. Restless legs syndrome: diagnostic criteria, special considerations, and epidemiology. A report from the restless legs syndrome diagnosis and epidemiology workshop at the National Institutes of Health. Sleep Med. 2003;4: 101-119.

95. Hornyak M, Kopasz M, Berger M, Riemann D, Voderholzer U. Impact of sleep-related complaints on depressive symptoms in patients with restless legs syndrome. J Clin Psychiatry. 2005;66: 1139-1145.

96. Picchietti D, Winkelman JW. Restless legs syndrome, periodic limb movements in sleep, and depression. Sleep. 2005;28:891-898.

97. Pearson VE, Allen RP, Dean T, Gamaldo CE, Lesagne SR, Earley CJ. Cognitive deficits associated with restless legs syndrome (RLS). Sleep Med. 2006; 7:25-30.

98. Peppard PE, Young T, Palta M, Skatrud J. Prospective study of the association between sleep-disordered breathing and hypertension. N Engl J Med. 2000;342:1378-1384.

99. Billars L, Hicks A, Bliwise D, et al. Hypertension risk and PLMS in restless legs syndrome. Sleep. 2007;30:A297-A298.

100. Walters AS, Rye DB. Review of the relationship of restless legs syndrome and periodic limb movements in sleep to hypertension, heart disease, and stroke. Sleep. 2009;32:589-597.

101. Silveira DC, Siddiqui F, Strus J, Fuentes K, Moussouttas M, Walters AS. Restless legs syndrome and cerebral microvascular ischemic disease. Neurology. 2007;68:A257.

102. Pennestri MH, Montplaisir J, Colombo R, Lavigne G, Lanfranchi PA. Nocturnal blood pressure changes in patients with restless legs syndrome. Neurology. 2007;68:1213-1218.

103. Winkelman JW. The evoked heart rate response to periodic leg movements of sleep. Sleep. 1999;22:575-580.
104. Winkelman JW, Shahar E, Sharief I, Gottlieb DJ. Associations of restless legs syndrome and cardiovascular disease in the Sleep Heart Health Study. Neurology. 2008;70:35-42.

105. Aukerman MM, Aukerman D, Bayard M, et al. Exercise and restless legs syndrome: a randomized controlled trial. J Am Board Fam Med. 2006;19:487-493.

106. Montplaisir J, Allen R, Walters A, Ferini-Strambi L. Restless legs syndrome and periodic limb movements during sleep. In: Roth T, Dement WC, editors. Principles and Practice of Sleep Medicine. 5th ed. Philadelphia: Elsevier; 2005.

107. Hornyak M, Grossmann C, Kohnen R, et al. Cognitive behavioral group therapy to improve patients' strategies for coping with restless legs syndrome: a proof-of-concept trial. J Neurol Neurosurg Psychiatry. 2008;79:823-825.

108. Von Scheele C, Kempi V. Long term effect of dopaminergic drugs in restless legs. A 2-year follow-up. Arch Neurol. 1990;47:1223-1224.

109. Early CJ, Allen RP. Pergolide and carbidopa/levodopa treatment of the restless legs syndrome and periodic leg movements in sleep in a consecutive series of patients. Sleep. 1996;19:801-810.

110. Garcia Borreguero D, Allen RP, Kohnen R, et al. Diagnostic standards for dopaminergic augmentation of restless legs syndrome: report from a World Association of Sleep Medicine-International Restless Legs Syndrome Study Group consensus conference at the Max Planck Institute. Sleep Med. 2007;8:520-530.

111. Paulus W, Trenkwalder C. Less is more: pathophysiology of dopaminergic therapy related augmentation in restless legs syndrome. Lancet Neurol. 2006;5:878-886.

112. Allen R, Becker PM, Bogan R, et al. Ropinirole decreases periodic leg movements and improves sleep parameters in patients with restless legs syndrome. Sleep. 2004;27:907-914.

113. Bogan RK, Fry JM, Schmidt MH, Carson SW, Ritchie SY; TREAT RLS US Study Group. Ropinirole in the treatment of patients with restless legs syndrome: a US-based randomized double-blind, placebocontrolled clinical trial. Mayo Clin Proc. 2006;81:17-27.

114. Montplaisir J, Nicolas A, Denesle R, Gomez Mancilla B. Restless legs syndrome improved by pramipexole: a double-blind randomized trial. Neurology. 1999;52:938-940.

115. Partinen M, Hirvonen K, Jama L, et al. Efficacy and safety of pramipexole in idiopathic restless legs syndrome: a polysomnographic dose-finding study - the PRELUDE study. Sleep Med. 2006;7: 407-417.

116. Trenkwalder C, Garcia Borreguero D, Montagna P, et al. Ropinirole in the treatment of restless legs syndrome: results from the TREAT RLS 1 study, a 12 week, randomised, placebo controlled study in 10 European countries. J Neurol Neurosurg Psychiatry. 2004;75:92-97.

117. Winkelman JW, Sethi KD, Kushida CA, et al. Efficacy and safety of pramipexole in restless legs syndrome. Neurology. 2006;67:1034-1039.

118. Montplaisir J, Fantini ML, Desautels A, Michaud M, Petit D, Filipini D. Long-term treatment with pramipexole in restless legs syndrome. Eur J Neurol. 2006;13:1306-1311.

119. Garcia Borreguero D, Grunstein R, Sridhar G, et al. A 52-week openlabel study of the long-term safety of ropinirole in patients with restless legs syndrome. Sleep Med. 2007;8:742-752.

120. Manconi M, Ferri R, Zucconi M, et al. First night efficacy of pramipexole in restless legs syndrome and periodic legs movements. Sleep Med. 2007;8:491-497.

121. Quilici S, Abrams KR, Nicolas A, et al. Meta-analysis of the efficacy and tolerability of pramipexole versus ropinirole in the treatment of restless legs syndrome. Sleep Med. 2008;9:715-726.

122. Trenkwalder C, Benes H, Poewe W, et al. Efficacy of rotigotine for treatment of moderate to severe restless legs syndrome: a randomised, double-blind, placebo-controlled trial. Lancet Neurol. 2008;7:595-604.

123. Happe S, Trenkwalder C. Role of dopamine receptor agonists in the treatment of restless legs syndrome. CNS Drugs. 2004;18: $27-36$ 
124. Bleumink GS, Van der Molen EM, Strijbos JH, Sanwikarja S, Van Puijenbroek EP, Stricker BH. Pergolide-induced pleuropulmonary fibrosis. Clin Neuropharmacol. 2002:25:290-293.

125. Danoff SK, Grasso ME, Terry PB, Flynn JA. Pleuropulmonary disease due to pergolide use for restless legs syndrome. Chest. 2001;120:313-316.

126. Horvath J, Fross RD, Kleiner Gisman G, et al. Severe multivalvular heart disease: a new complication of the ergot derivative dopamine agonists. Mov Disord. 2004;19:656-662.

127. Baseman DG, O’Suilleabhain PE, Reimold SC, Laskar SR, Baseman JG, Dewey RB Jr. Pergolide use in Parkinson disease is associated with cardiac valve regurgitation. Neurology. 2004;63:301-304.

128. Garcia Borreguero D, Larrosa O, De la Llave Y, Verger K, Masramon X, Hernandez G. Treatment of restless legs syndrome with gabapentin: a double-blind, cross-over study. Neurology. 2002;59:1573-1579.

129. Happe S, Sauter C, Klösch G, Saletu B, Zeitlhofer J. Gabapentin versus ropinirole in the treatment of idiopathic restless legs syndrome. Neuropsychobiology. 2003;48:82-86.

130. Oertel WH, Trenkwalder C, Zucconi M, et al. State of the art in restless legs syndrome: practice recommendations for treating restless legs syndrome. Mov Disord. 2007;22:S466-S475.

131. Trenkwalder C, Hening WA, Montagna P, et al. Treatment of restless legs syndrome: an evidence-based review and implications for clinical practice. Mov Disord. 2008;23:2267-2302.

132. Walters AS, Winkelmann J, Trenkwalder C, et al. Long-term follow-up on restless legs syndrome patients treated with opioids. Mov Disord. 2001;16:1105-1109.

133. Walters AS, Wagner ML, Hening WA, et al. Successful treatment of the idiopathic restless legs syndrome in a randomized double-blind trial of oxycodone versus placebo. Sleep. 1993;16:327-332.

134. Ondo WG. Methadone for refractory restless legs syndrome. Mov Disord. 2005;20:345-348.

135. Lauerma H, Markkula J. Treatment of restless legs syndrome with tramadol: an open study. J Clin Psychiatry. 1999;60:241-244.

136. Vetrugno R, La Morgia C, D'Angelo R, et al. Augmentation of restless legs syndrome with long-term tramadol treatment. Mov Disord. 2007;22:424-427.

137. Saletu M, Anderer P, Saletu-Zyhlarz G, et al. Restless legs syndrome (RLS) and periodic limb movements disorder (PLMD): acute placebocontrolled sleep laboratory studies with clonazepam. Eur Neuropsychopharmacol. 2001;11:153-161.

138. Hening W, Allen R, Earley C, Kushida C, Picchietti D, Silber M. The treatment of restless legs syndrome and periodic limb movement disorder. An American Academy of Sleep Medicine Review. Sleep. 1999;22:970-999.

139. Huiqi Q, Shan L, Mingcai Q. Restless legs syndrome in uremic patients is related to the frequency of hemodialysis sessions. Nephron. 2000;86:540.

140. Collado-Seidel V, Kohnen R, Samtleben W, et al. Clinical and biochemical findings in uremic patients with and without restless legs syndrome. Am J Kidney Dis. 1998;31:324-328.

141. Winkelmann J, Stautner A, Samtleben W, Trenkwalder C. Long-term course of restless legs syndrome in dialysis patients after kidney transplantation. Mov Disord. 2002;17:1072-1076.
142. Molnar MZ, Novak M, Ambrus C, et al. Restless legs syndrome in patients after renal transplantation. Am J Kidney Dis. 2005;45:388-396.

143. Manconi M, Govoni V, De Vito A, et al. Restless legs syndrome and pregnancy. Neurology. 2004;63:1065-1069.

144. Tunc T, Karadaq YS, Dogulu F, Inan LE. Predisposing factors of restless legs syndrome in pregnancy. Mov Disord. 2007;22:627-631.

145. Patrick LR. Restless legs syndrome: pathophysiology and the role of iron and folate. Altern Med Rev. 2007;12:101-112.

146. Winkelman JW, Finn L, Young T. Prevalence and correlates of restless legs syndrome symptoms in the Wisconsin Sleep Cohort. Sleep Med. 2006; 7:545-552.

147. Sommer M, Bachmann CG, Liebetanz KM, et al. Pregabalin in restless legs syndrome with and without neuropathic pain. Acta Neurol Scand. 2007;115:347-350.

148. Guilleminault C, Palombini L, Pelayo R, Chervin RD. Sleepwalking and sleep terrors in prepubertal children: what triggers them? Pediatrics. 2003;111:e17-e25.

149. Konofal E, Arnulf I, Lecendreux M, Mouren MC. Ropinirole in a child with attention-deficit hyperactivity disorder and restless leg syndrome. Pediatr Neurol. 2005;32:350-351.

150. Walters AS, Mandelbaum DE, Lewin DS, Kugler S, England SJ, Miller M. Dopaminergic therapy in children with restless legs/periodic limb movements in sleep and ADHD. Dopaminergic Study Group. Pediatr Neurol. 2000;22:182-186.

151. Picchietti MA, Picchietti DL. Restless legs syndrome and periodic limb movement disorder in children and adolescents. Semin Pediatr Neurol. 2008;15:91-99.

152. Simakajornboon N, Gozal D, Vlasic V, Mack C, Sharon D, McGinley B. Periodic limb movement in sleep and iron status in children. Sleep 2003;26:735-738.

153. Konofal E, Lecendreux M, Arnulf I, Mouren MC. Iron deficiency in children with attention-deficit/hyperactivity disorder. Arch Pediatr Adolesc Med. 2004;158:1113-1115.

154. Pennestri M, Montplaisir J, Colombo R, et al. Nocturnal blood pressure changes in patients with restless legs syndrome. Neurology. 2007;68:1213-1218.

155. Earley CJ. Restless legs syndrome. N Engl J Med. 2003;348: 2103-2109.

156. Jankovic J. Post-traumatic movement disorders: central and peripheral mechanisms. Neurology. 1994;44:2008-2014.

157. Bhatt M, Desai J, Mankodi A, et al. Posttraumatic akinetic-rigid syndrome resembling. Parkinson's disease: a report on three patients. Mov Disord. 2000;15:313-317.

158. Van Hilten JJ, Geraedts EJ, Marinus J. Peripheral trauma and movement disorders. Parkinsonism Relat Disord. 2007;13:S395-S399.

159. Krauss J, Jankovic J. Movement disorders after TBI. In: Zasler ND, Katz D, Zafonte R, editors. Brain Injury Medicine: Principles and Practice. New York: Demos; 2007:469-489.

160. Rangarajan S, Rangarajan S, D’Souza GA. Restless legs syndrome in an Indian urban population. Sleep Med. 2007;9:88-93.

161. Gupta R, Lahan V, Goel D. Translation and validation of International Restless Leg Syndrome Study Group rating scale in Hindi language. Ann Indian Acad Neurol. 2011;14:257-261.
Journal of Parkinsonism \& Restless Legs Syndrome

\section{Publish your work in this journal}

Journal of Parkinsonism and Restless Legs Syndrome is an online, open access, peer-reviewed journal. The journal publishes review articles, historical reviews, original research articles, case reports, letters to the editor, clinical teaching cases, neuroradiology highlights, neuropathology highlights, neuropsychiatry highlights, autobiographies, conference

\section{Dovepress}

proceedings, abstracts and book reviews. The manuscript management system is completely online and includes a very quick and fair peerreview system, which is all easy to use. Visit http://www.dovepress.com testimonials.php to read real quotes from published authors. 